\title{
Assessment of Farmer's Perception and Adoption of Agroforestry Practices: The Case of Assosa District, Western Ethiopia
}

\author{
Abdu Arage \\ Natural Resource Management, Mekdella Amba University, Addis Ababa, Ethiopia \\ Email address: \\ Abduarage81@gmail.com \\ To cite this article: \\ Abdu Arage. Assessment of Farmer's Perception and Adoption of Agroforestry Practices: The Case of Assosa District, Western Ethiopia. \\ American Journal of Applied Scientific Research. Vol. 7, No. 2, 2021, pp. 15-21. doi: 10.11648/j.ajasr.20210702.11
}

Received: March 9, 2021; Accepted: May 21, 2021; Published: May 31, 2021

\begin{abstract}
Agroforestry is a sustainable land management system which integrate production of crops, forest trees and animals at the same time on the same unit of land and put on management practices that are friendly with local population. Population growth and continuous use of agricultural land are the major causes of soil fertility reduction in rural Ethiopia and also in the study area. Existing land suitable for agriculture or crop production, grazing or forestry is decreasing while human populations are gradually increasing. As the population continues to grow, the gap between supply and demand for agricultural land continues to expand. Such a situation is leading to severe land use conflicts between the crop production and other type of land use such condition leading to reduction of 4 agroforestry practice. Despite this, one of the solutions to meet diverse people's requirement with fixed land is through the application of agroforestry which is more advantageous than mono cropping. Agroforestry practices play important role so in order to strengthen and make the existing practice effective. This study was conducted to assess adoption of agroforestry practices in assosa woreda. The collected data were analyzed using descriptive statistics. The results showed that most of the sampled house hold heads $89(64.5 \%)$ are not practicing agroforestry technology in the study area. Some of the major Agroforesty practices that have been commonly implemented include alley cropping, homegardens, and tree on crop land. The attitude of farmers towards agroforestry practice is positive and is well understood that agroforestry increase farm income, soil fertility, decreased complete crop failure and helping resolving fuel wood demands. Agroforestry technologies are not very well practiced so far in Assosa destrict due to different reasons. The government and other concerned organization should try to reduce the independent factors that affect adoption of agroforestry practice significantly through providing the necessary materials and creating awareness to farmers.
\end{abstract}

Keywords: Agroforestry, Adopter, Non-adopter, and Perception

\section{Introduction}

Agroforestry is a sustainable land management system which integrate production of crops, forest trees and animals at the same time on the same unit of land and put on management practices that are friendly with local population [2]. Agroforestry is an integration of trees and shrubs with crops and/or livestock which can give higher income for rural people and forest production along with conserving natural resources [13].

Most farmers in the world in recent years have faced many constraints including high population, high levels of poverty, food insecurity, and climate change among others. These farmers are slowly changing to agroforestry practices as alternative means of improving their situations [7]. A study conducted in over 700 households in east Africa found that at least $50 \%$ of those households had started planting trees ten years ago on their farms to branch out their yield [12].

By mixing trees on farms and in the agricultural landscape, it supports to diversify and sustain yields for enhanced economic, environmental and social benefits [8]. Agroforestry takes advantage of the interactive benefits from combining trees and shrubs with crops and/or livestock production. The tree reduces the effects of climate change by serving to reducing erosion, increasing water, soil quality and gives yields of fruit, and medicinal products additionally to 
their usual harvest [12]. According to [15], adoption occurs when the farmers have interest for use of new technology for addressing a need.

Ethiopia is a country of small holder farmers characterized by rain fed agriculture. Over 85 per cent of the total population of Ethiopia are rural and depend on agriculture, the sector on which the large majority of the poor people depends. It is the engine of overall economic growth of Ethiopia and comprises about $41.3 \%$ of GDP, generates $90 \%$ of foreign exchange incomes and employs more than $80 \%$ of the population [13]. Ethiopia's economy is mostly dominated by subsistence agriculture of crop and livestock farming. In Ethiopia, the forest area is diminishing increasingly, resulting ecological imbalance, environmental degradation and lowagricultural production. Population increase and subsequent increase in human needs and lack of appropriate technologies which integrate agriculture and forestry are some of the major causes. Agroforestry offers a potential solution to the problems of declining rural agricultural production [9]. There are different types of traditional agroforestry practice in different parts of Ethiopia, and there are new agroforestry technologies like homegardens, alley cropping, and wind breaks started by several institutions at a national level across different land use systems [6]. Agroforestry is now developing as the likely land use option to sustain agricultural productivity and livelihoods of farmers [16]. However, existing land suitable for agriculture or crop production, grazing or forestry is decreasing while human populations are gradually increasing. As the population continues to grow, the gap between supply and demand for agricultural land continues to expand. Such a situation is leading to severe land use conflicts between the crop production and other type of land use such condition leading to reduction of agroforestry practice. Despite this, one of the solutions to meet diverse people's requirement with fixed land is through the application of agroforestry which is more advantageous than mono cropping [11]. The main objective is to asses' farmers perception and adoption of agroforestry practices in the study area.

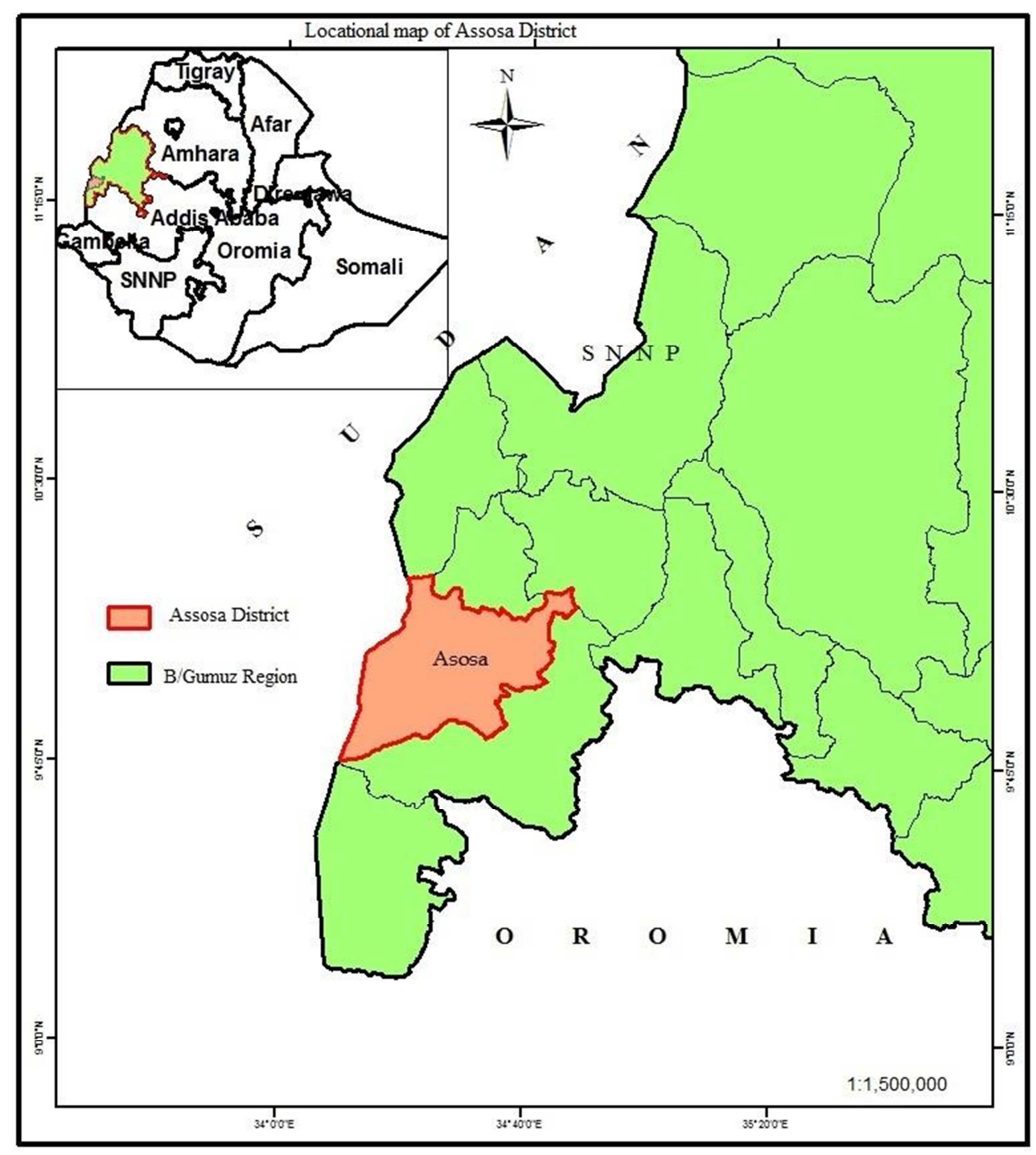

Source: Assosa District Office of Agriculture and Rural Development

Figure 1. Location map of Assosa district. 


\section{Research Methodology}

\subsection{Description of the Study Area}

The study area can be described according to location, climate, land use, soil type and cropping practices of the people as well as the number of population in the kebele. It is described bellow Location: The study was done in Benishangul-Gumuzregion namely in Assosa woreda which is one of the twenty woreda in the region. The district is bordered byKomosha and Kurmuk in the north; Menge woreda in the north east; Oda Buldigilu in the east; Bambasi in the south east; Mao-Komo special woreda in the south and Sudan in the west. Geographically, Assosa district is located between geographical coordinates of $9^{\circ} 30^{\prime} \mathrm{N}-11^{\circ} 39^{\prime} \mathrm{N}$ latitude and $34^{\circ} 20^{\prime} \mathrm{E}$ to $36^{\circ} 30^{\prime}$ ELongitude. The estimated land area of the district is 2330 square kilometers [1]. The area are selected because there is few research studied in this area.

Topography: the topography of the woreda contains mountainous (30\%), plain (52\%) and depression (18\%). The altitude of the woreda ranges from 558 to 2,729 meters above sea level. Generally assosa woreda is characterized by rugged terrain and plain surface.

Demography: The 2007 national census reported total populations for this district are about 104, 147, from this 52,968 were men and 51,179 were women. From this estimated total population of the district, about $76.75 \%$ live in rural area while the remaining $23.25 \%$ where urban dwellers. The three largest ethnic in assosa woreda were the Amhara (53\%), Berta (34\%), and Oromo (9.4\%) and all other ethnic groups made up 3.6\% of the population. The majority of the people are Muslims, with $63.27 \%$ of the population, while $31.18 \%$ of the population practices orthodox Christianity and 5.23\% were Protestants (CSA, 2007). With an area of 2330 square kilometers, the district has a population density of 39.9 persons per square kilometer. Generally, this population density is higher than Benishangul Gumuz regional state, 15 persons per square kilometer, and lower than that of the country, 67 persons per square kilometer. The number of rural households in the district is 18,811. According to CSA (2007), the average household size of the district is 4.93 . This is almost the same as to the country level average household size of 4.9 for rural.

Climate: The annual average temperature and total annual rainfall of the woreda ranges between $15.4^{\circ} \mathrm{C}-29.6^{\circ} \mathrm{C}$ and $1132 . \mathrm{mm}$ respectively. On the basis of altitudinal variation the woreda has been categorize as kola $(90 \%)$ and Woina dega $(10 \%)$.

Land use/land covers: based on assosa woreda agriculture and rural development office (2016), the total area of the woreda was estimated to be 4767 hectares. The cultivated land is the dominant land use type, which account $51.17 \%$, settlement and construction $(25 \%)$, grazing land $(15 \%)$, and waste land $(8.83 \%)$

Agricultural activities: Mixed farming (crop production and livestock rearing) is the dominant source of livelihoods for the majority of the population in the area. The crop production is dominated by rain fed agriculture while irrigation is practiced on small scale level using traditional stream diversion methods to produce horticultural crops and some food crops (e.g. maize).

The major crops produced in Assosa district are: sorghum, maize, teff among food crops, haricot bean, noug, soya bean, sesame among oil crops, and horticultures are tomato, onion, pepper, head cabbage, carrot, potatoes, sweet potato, mango, banana, papaya, avocado. Moreover, livestock rearing is another agricultural activity practiced in the district. The major livestock reared in the woreda are cattle, goats, sheep and poultry. Livestock management is undertaken in a traditional way. Animals are released to open field and forest areas for free grazing indicating that there is a livestock management problem in Assosa district.

\subsection{Research Approaches and Design}

The study were used both qualitative and quantitative (mixed) approach to identify and asses determinant factors that affects adoption of agroforestry practice in the study area. The study was use cross sectional descriptive socio economic survey design. According to [14] descriptive survey design is suitable since it contains gathering information in order to response questions about the study. [10] states that descriptive design is dealing with collecting, describing, analyzing and reporting situations related to the study.

\subsection{Sampling Technique and Sample Size}

Purposive and simple random sampling techniques were used. A two-stage simple random sampling technique was applied to select sample households by taking different factors into consideration such as time, research cost, human resource, topography, environmental condition, accessibility and availability of transport. In the first stage, eight Kebeles were randomly selected out of 74 rural kebele in the woreda. In the second stage, household heads were selected randomly proportional to size of households in the kebele. The reason for using simple random sampling is that the kebeles are located approximately in the same agro-ecological zone (kola). This method of sample selection was given each kebele and every household head in each kebele a chance of being included in the sample. Therefore, the sample selections were free of bias. Purposive sampling was made to select sample for key informant interviews as a result kebeles agricultural experts and kebele administrators was selected purposively in the selected kebeles.

The sample size was considered to be the major part of all statistical analysis. The computation of the appropriate sample size was considered the most important and difficult step in statistical study. To determine the sample size of the study the researcher was applied the formula.

$$
n=\frac{z^{2} p q}{d^{2}}
$$

Where $n=$ required sample size (when population is $>10,000), Z=95 \%$ confident limit $(=1.96)$

$\mathrm{p}=$ proportion of population to be included in the sample 
which is $10 \%(0.1)$ of the population

$\mathrm{q}=1-\mathrm{P}=1-0.1=0.9, \mathrm{~N}=$ total number of population $\mathrm{d}=$ margin of error $(5 \%=0.05) n=\frac{(1.96)^{2} * 0.1 * 0.9}{(0.5)^{2}}=3.842 * 0.1 * 0.9$ / $0.0025=0.346 / 0.0025=0.35 / 0.0025=138$

$\mathrm{n}=138$ therefore, the sample size for study is 138 .

After determining the sample size for the study area, the next step were determining the number of households from the eight sampled kebeles using probability proportional to size (PPS) method to make equal representation of households.

$\mathrm{ni}=\frac{\mathrm{nxNi}}{\sum \mathrm{Ni}}$ Where $\mathrm{n}=$ determined sample size the research usedni $=$ households of the $\mathrm{i}^{\circ}$ kebele, and $\mathrm{Ni}=$ total households of the $\mathrm{i}^{\circ}$ kebele (Table 2)

Table 1. Number of total and sample households of study area.

\begin{tabular}{lll}
\hline Kebeles & Total households & Sampled households \\
\hline Amba 14 & 238 & 15 \\
Mengele 33 & 381 & 24 \\
Abrahamo & 309 & 20 \\
Nebar & 236 & 15 \\
Selga 22 & 267 & 17 \\
Komshiga 28 & 270 & 17 \\
Amba 8 & 216 & 14 \\
Amba 17 & 245 & 16 \\
Total & 2162 & 138 \\
\hline
\end{tabular}

\subsection{Data Sources and Collection Methods}

Both primary and secondary data was used for this study. To collect both Primary and secondary data the following instrument were used.

\subsubsection{Primary Data}

\section{i. Questionnaire}

Primary data was collected directly from the sample households of farmers in the district by preparing and asking semi-structured questionnaire through interview of household heads in selected kebeles. The questionnaire was consisted of different types of questions or items related to factor affecting adoption of agroforestry practice and household background.

Questionnaire were developed and used in order to allow the respondents to freely express their opinion on questions associated to the research topics. Enumerators who are familiar with the study area, who can understand everything in the study area and who have prior experience in data collection were taken. Those enumerators were trained regarding the content of the questionnaire and data collection methods.

\section{ii. Interview}

The key informants in the study site was interviewed in order to get general Information about the farmers, especially the information related to factor affecting adoption of Agroforestry practice in the study area. Interviews were filled by face to face asking of the respondents.

\section{iii. Direct Observation}

In order to be familiar with local people, the researcher was directly observed study site by direct observation, and understands about agricultural production of farmers, natural and socioeconomic conditions of the farmers in the study site.

\subsubsection{Secondary Data}

Secondary data were collected by reviewing and careful examination of documents, research reports, published and unpublished writings, different journals, internet websites etc. It was also collected from agricultural and land office.

\subsection{Data Analysis}

A simple qualitative analysis technique such as percentage and frequency distributions and frequency bar charts was employed. Descriptive statistics were also employed to assess agroforestry practice in the study area.

All of the above mentioned analysis descriptive statistics and percentage and frequency distribution were analyzed by using Statistical Software Package for Social Science version 21 (SPSS).

Finally the results were summarized in a table form so that the analysis and meaningful interpretations of results were made to draw conclusions. The qualitative data collected through key informant interview, and physical observation was described and summarized.

\section{Result and Discussion}

This chapter discussed the different specific objective of the study. The first section discuses the assessment of agroforestry practice in the study area and perception of farmers towards agroforestry practice were discussed finally.

\subsection{Adoption of Agroforestry Practice in the Study Area}

The figure 2 below shows the level of adoption of agroforestry practice which is categorized as adopter and non-adopter only in the study area. Adoption of agroforestry means using forest resource and agriculture activity together. However most of the respondents are not practice agroforestry technology in the study effectively due to different factor. Mostly the farmers in the study area practice only cropping rather than applying agroforestry practice that is the reason why the level of non adopter are greater than adopter of agroforestry practice.

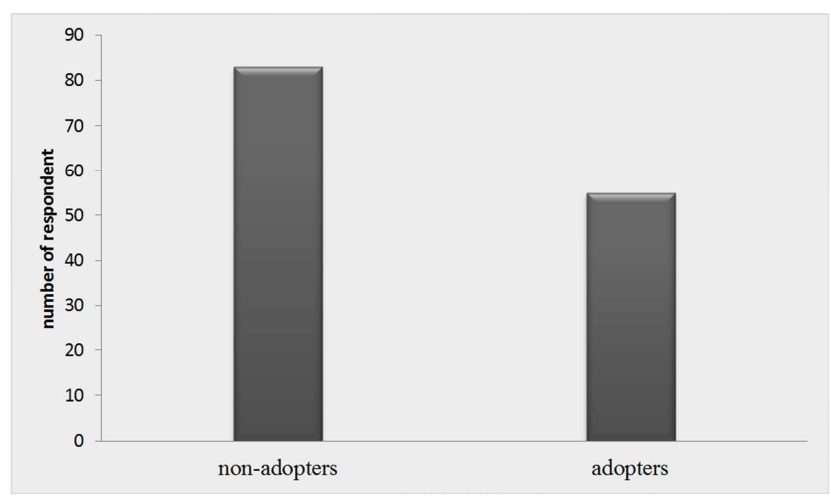

Figure 2. Agroforestry adoption level in the study area.

3.2. Types of Agroforestry Practice in the Study Area 
Agroforestry practices have highly important in reducing soil erosion that affect the fertility of the soil in the study area. It also have a vital role in improving the agricultural and forest production by providing food, fodder and income for agroforestry adopter farmers in the study area. Some of the most common agroforestry practice that has practiced in the study area by agroforestry technology adopters is the following.

\subsubsection{Alley Cropping}

Alley cropping is an agroforestry practice contains growing of food crop in the middle of hedge rows of planted trees and shrubs. Figure 3 shows that out of 49 agroforestry practice adopter $19(13.8 \%)$ respondents are practice alley cropping in their farm land. Most farmers practice alley cropping that give high yields since their farm size are small (on average 1.5ha). This finding agrees with found that when farm sizes decrease, they may become more involved in higher yielding but more labour intensive system such as alley cropping.

\subsubsection{Home Gardens}

Home gardens are one type of agroforestry technology that includes multiple crops growing with tree and domestic animal around the homestead. A home garden is one of the agroforestry system practiced in the study area. Crops such as Coffee, and numerous kinds of vegetables are dominant components of the study area homegerdens. Fruit trees like Avocado, Mango, and Papaya are also practiced in homegardern agroforestry. Trees such as Cordia africana, Grevillea robusta, and Acacia species are among the species that form the upper story of home garden. Home gardens integrated mostly fruit trees combined with fodder crops, vegetable, beans and even maize on small gardens near to homestead. The main objectives of this practice are to produce food, construction materials and to gain income from the product. As figure 3 shows out of 49 agroforestry adopters $18(13.0 \%)$ are practicing home gardens around their homestead. This is similar with the finding of Sharma (1995) who pointed out that farmers in most case have habit to adopt multipurpose and fast growing tree specious that gives benefit in short period of time rather than those take long time to generate income. The result is also similar with the findings of $[3,4]$.

\subsubsection{Tree on Crop Land}

Tree on crop land are other type of agroforestry system that include tree grown together with crop, in the same unit of land. The tree grown may be natural or planted they are randomly distributed on crop land. The main objectives of this agroforestry practice are to increase soil fertility by providing litter and preserve soil moisture for crops in the farm land. Dispersed trees grown in farmlands characterize a large part of the study areas. Some good examples of this practice include scattered Cordia africana, Acacia species, and other in the farmland.

The practice of growing and maintenances of scattered trees on cropland may be based on protection and management of selected matured trees already on the site.

Generally the figure 3 shows out of 49 adopters only 12 $(8.7 \%)$ of respondent are practicing trees on crop land. Particularly the decision to adopt new agroforestry technology may vary depending on their farm land size, as when their farm land size large and labour availability is low, then the farmers can be more ready to adopt agroforestry practice such as tree on crop land.

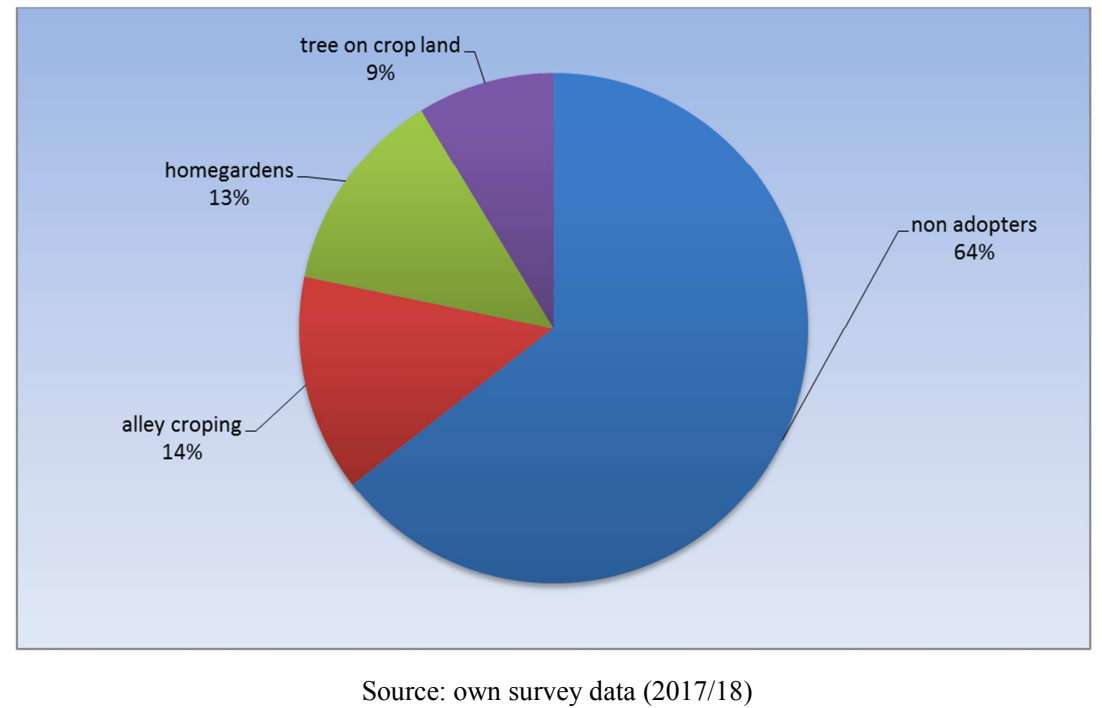

Figure 3. Types of agroforestry practice done in the study area.

\subsection{Farmer's Perceptions About Agroforestry Technology}

The farmer's interest for adoption of new agroforestry technology depends on their perception about agroforestry practice. Assessing farmers attitude towards agroforestry practice are important to understand farmers knowledge. Farmer's perception towards agroforestry practice includes awareness and knowledge of farmers about agroforestry. As 
table 2 below shows most of the respondents were aware of both environmental and economic benefits of agroforestry. More specifically most of the respondent's perception towards agroforestry technology is that it increased farm income, soil fertility, decreased complete crop failure and a potential of solving their fuel wood needs. The farmers also believed that agroforestry technology is more profitable and less risky than other agricultural alternatives.

However the main problems of the farmer's attitude towards agroforestry are their negative thinking that this activity takes long time to generate income as a result they tried to practice activities that generate income in short period such as to fulfill their basic needs. The combination of different varieties of products which are both subsistence and income generating, support farmers to fulfill basic needs and decreased the risk of complete crop failure.

The results in table 2 shows that most of the respondents agreed that agroforestry practice increase soil fertility $75.4 \%$ of the respondents, $21.7 \%$ of the respondents are strongly agree and $1.4 \%$ neutral only the rest are disagree perception.
The farmer's perceptions about agroforestry practice increase farm income are positive about $60.17 \%$ are agree and $37.0 \%$ are strongly agree the rest of the respondent are disagree about agroforestry practice increase farm income.

Their perception towards agroforestry practice reduce complete crop failure $50.0 \%$ are agree, $33.3 \%$ strongly agree, $4.3 \%$ neutral and the rest of the respondents are dis agree response. The fourth statement are about agroforestry practice improve the surrounding conditions and for this more respondents are neutral, disagree response $45.7 \%$ agree, $18.8 \%$ strongly agree, $26.1 \%$ neutral, $8.0 \%$ dis agree, $1.4 \%$ strongly disagrees. The other statements are agroforestry practice takes long time to generate incomes and more respondents are $54.3 \%$ are agree, $34.8 \%$ are strongly agree, and the other are disagree and neutral response. The farmer's positive perception is shown as necessary steps in adoption of agroforestry practice [7]. Similarly negative attitude among the farmers may be the main reasons for less adoption of agroforestry technology [5].

Table 2. Farmers perception towards agroforestry practice in the study area.

\begin{tabular}{|c|c|c|c|c|c|c|}
\hline \multirow{2}{*}{ Statement } & & \multicolumn{5}{|c|}{ Respondents Response (perceptions) } \\
\hline & & 1. strongly disagree & 2. disagree & 3. neutral & 4. agree & 5. strongly agree \\
\hline \multirow{5}{*}{$\begin{array}{l}\text { Agrofore } \\
\text { stry Practice }\end{array}$} & Increase soil fertility & $1(0.7 \%)$ & $1(0.7 \%)$ & $2(1.4 \%)$ & $104(75.4 \%)$ & $30(21.7 \%)$ \\
\hline & Increase farm income & $1(0.7 \%)$ & $3(2.2 \%)$ & 0 & $83(60.1 \%)$ & $51(37.0 \%)$ \\
\hline & Reduce complete crop Failure & $3(2.2 \%)$ & $14(10.1 \%)$ & $6(4.3 \%)$ & $69(50.0 \%)$ & $46(33.3 \%)$ \\
\hline & Improve surrounding Conditions & $2(1.4 \%)$ & $11(8.0 \%)$ & $36(26.1 \%)$ & $63(45.7 \%)$ & $26(18.8 \%)$ \\
\hline & Takes long time to generate incomes & $6(4.3 \%)$ & $8(5.8 \%)$ & $1(0.7 \%)$ & $75(54.3 \%)$ & $48(34.8 \%)$ \\
\hline \multicolumn{2}{|c|}{ Do you think extension service are satisfactory } & $40(29.0 \%)$ & $62(44.9 \%)$ & $8(5.8 \%)$ & $24(17.4 \%)$ & $4(2.9 \%)$ \\
\hline
\end{tabular}

Source: own survey data $(2017 / 18)$

The figure 4 below shows the farmer perception on the level of significant agroforestry practice have in minimizing deforestation, out of the total respondents $26.8 \%$ are highly significant, $58.0 \%$ are significant and $15.2 \%$ are not significant response. So most of the respondents are positive perceptions as agroforestry practice are significant effect in minimizing deforestations.

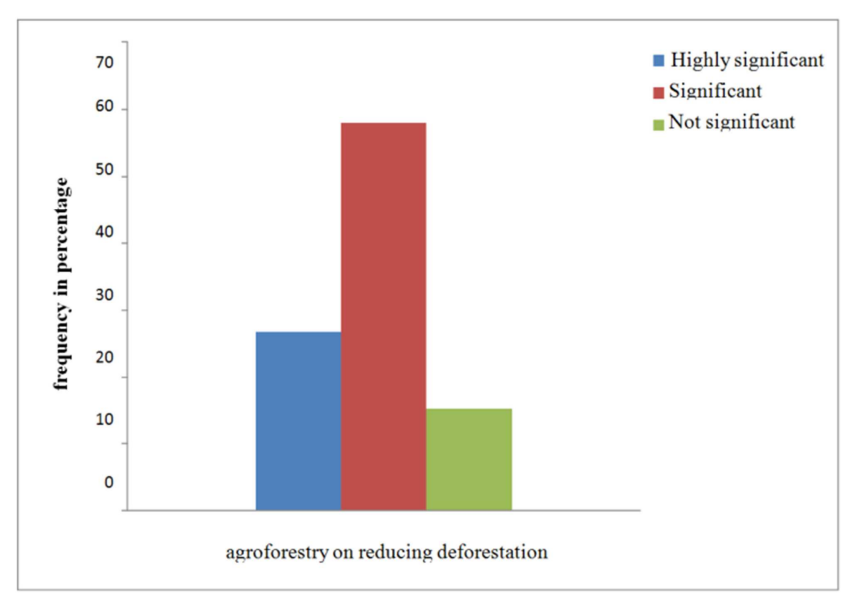

Source: own survey data $(2017 / 18)$

Figure 4. Farmers perception towards agroforestry practice minimize deforestation.

\section{Conclusion and Recommendations}

\subsection{Conclusion}

This study addressed assessments of agroforestry practice and perception of farmers towards agroforestry practice in Assosa Woreda. Some of the major Agroforestry practice that has commonly practiced in the study area is alley cropping, homegardens, and tree on crop land. From this the researchers conclude that agroforestry technologies that are practice in the study area are ${ }^{\circ}$ three or four types. The perceptions of farmers towards agroforestry practice are positive and they are aware that agroforestry practices increase farmers' income, soil fertility, decreased complete crop failure and a potential for solving fuel wood shortages. The main challenges associated with adoption of agroforestry practices are the long time it takes to give benefit and the demands for labour and capital to practice agroforestry technology as a result they tried to practice activities that generate income in short period and with limited capital to fulfill their basic needs.

\subsection{Recommendations}

Based on the main finding for the study the following recommendations are made

1) Agroforestry practices that are practice in the study area 
are only three or four it should be diversified through providing the necessary material for adoption of more agroforestry practice for farmers.

2) Even if farmer's perceptions towards agroforestry practice are positive most of the farmers still not adopted agroforestry practice in the study area. So adoption of agroforestry practice should be improved in the woreda.

3) Further researches should be done on assessment of adoption of agroforestry practice in the future in the study area.

\section{References}

[1] ADBoARD (Assosa District Bureau of Agricultureand Rural Development), 2012. District Annual Report of Benishangul Gumuz Regional State, Ethiopia 2012.

[2] Barrett, C. B. (2002). The challenge of stimulating adoption of improved natural resources Management practices in Africa.

[3] Berhane Kidane, Kindu Mekonnon, Fekede Feyissa, Chilot Yirga (2004). African Highland Initiative, Integrated natural resource management in practice: Enabling communities to improve mountain livelihoods and landscapes.

[4] Berhane Kidane, Mehari Alebachew, Kassahun Bekele, Kindu Mekonnen, Laura A German (2008). Participatory Tree Nursery Management and Tree Planting: Experiences from Gallessa Watershed, Dendi District, Western Shewa zone of the Oromia Region, Ethiopia. In: Zenebe Admassu, Kindu Mekonnnen and Yohannes Gojjam (eds.), 2008.

[5] Chauhan, S. K., Nanda, R. K., \& Brar, M. S. (2009). Adoption of poplar-based agroforestry as an approach for diversified agriculture in Punjab. Indian Forester, 135 (5), 671.
[6] Dechasa, Jiru. 1990. Current Agroforestry Systems in Ethiopia, Proc. 2nd NRC conference, pp 181-185.

[7] Franzel S, Phiri D, Kwesiga F (2002). Assessing the adoption potential of improved fallows in Eastern Zambia. pp. 37-64.

[8] Garrity, D. P. (2006). Science-based agroforestry and the Millennium Development Goals. World Agroforestry into the Future (pp. 3-8).

[9] Jiregna, G. 1998. Decomposition and Nutrient release from leaves of croton macrostachyus and millettia ferruginea for soil improvement in agroforestry system. Skinnskatteberg.

[10] Kothari, C. K. (1995). Research methodology: Methods and Techniques. New Delhi: New Age International Ltd Publishers.

[11] Mcneely AJ, Schroth G (2006) Agroforestry and biodiversity conservation traditional practices, present dynamics and lessons for the future. Biodiversity Conservation 15: 549-554.

[12] Mercer, D. E. (2004) Adoption of agroforestry innovations in the tropics: a review Agroforestry, 61, 311-328.

[13] MoFED (Ministry of Finance and Economic Development), 2012. Growth and Transformation Molua EL., (2005). The economics of tropical agroforestry systems: the case of agroforestry Farms in Cameroon. For Policy Econ 7 (2): 199211.

[14] Mugenda, A. G. (2003). Research Methods: Quantitative and Qualitative Approaches. Nairobi: Acts Press.

[15] Rogers, E. M. (2003). Diffusion of Innovations (Fifth ed.). New York.

[16] Syampunani, S., P. W. Chirwa, F. K. Akinnifest \& O. C. Ajayi. 2010. The potential of using Agroforestry as a win win solution to climate change mitigation and adaptation and Meeting food security challenges in Southern Africa. Systems, 61, 311-328. 